\title{
Embryo Development Alteration in Rats Treated with Lapachol
}

\author{
Juliana Maganha, Evelise de Souza Rocha, Marcos Antônio Fernandes Brandão, Vera \\ Maria Peters and Martha de Oliveira Guerra* \\ Centro de Biologia da Reprodução; Universidade Federal de Juiz de Fora; direcao.cbr@ufj.edu.br; \\ martha.guerra@ufj.edu.br; 36001-970; Juizde Fora-MG - Brasil
}

\begin{abstract}
Lapachol, a naphthoquinone extracted from plants of the genus Tabebuia (family Bignoneaceae), showed multiple therapeutic activities. Pregnant Wistar rats were treated with Lapachol from the $1^{\text {st }}$ to the $4^{\text {th }}$ (pre-implantation period) and from $5^{\text {th }}$ to $7^{\text {th }}$ (implantation period) post insemination day (PID). Mothers were sacrificed on the $5^{\text {th }}$ or on the $15^{\text {th }}$ PID. Number of corpora lutea, preimplantation embryo, blastocysts, live and dead fetuses and resorptions were counted. There were no signs of maternal toxicity. The number and the morphology of embryos, during oviduct development (pre-implantation period), did not seem to be affected by this drug, but during the implantation period, lapachol was toxic causing the death of embryos and intrauterine growth retardation.
\end{abstract}

Key words: Lapachol, Embryo development, Rat, Reproductive toxicity

\section{INTRODUCTION}

Lapachol is a naphthoquinone [2-hydroxy-3-(3methyl-2-butenyl-)-1,4-naphthoquinone], extracted from the bark of various plant species of the genus Tabebuia (family Bignoneaceae) Rao, 1974; Linardi et al., 1975; Saizarbitoria et al., 1997; Kumagai et al., 1998; Knecht et al., 2000). Among them, Tabebuia ochracea, which is known in Brazil as 'ipê amarelo' is largely distributed in the country, being found from the Amazon to the Paraná state (Gentry, 1992).

A large number of therapeutic activities have been attributed to lapachol and its derivatives such as prevention against Schistosoma mansoni cercarial skin penetration (Austin, 1974; Pinto et al., 1977), was effective against Biomphalaria glabrata (Santos et al., 2000; Lima et al., 2002; Silva et al., 2005), bacteria and fungi (Guiraud et al., 1994;
Binutu et al., 1996; Rothery et al., 1998); virus (Lagrota et al., 1987; Sacau et al., 2003), Trypanosoma cruzi (Austin, 1974; Lopes et al., 1978; Pinto et al., 1987; Chiari et al., 1991; Duarte et al., 2000) and showed antimalarial activity (Andrade-Neto et al., 2004) involving the erythrocytic stages of Plasmodium falciparum (Carvalho et al., 1998). It also has antiinflammatory (Duarte et al., 2000, Almeida, 1990), analgesic (Grazziotin et al., 1992), antipsoriatic (Muller et al., 1999), and antineoplasic activities (Santana et al., 1968, Morrison et al., 1970, Rao, 1974; Linardi et al., 1975; Saizarbitoria et al., 1997, Duarte et al., 2000, Sieber et al., 1976; Hodnett et al., 1983; Houghton et al., 1994; Almeida et al., 1988; Balassiano et al., 2005).

On the general toxicology of lapachol, Santana et al. (1968) and Morrison et al. (1970) have established the LD-50 of this drug in mice and

* Author for correspondence 
rats. It is known that when administered to pregnant rats during the fetogenesis period, lapachol is fetotoxic leading to fetal growth retardation (Felício et al., 2002). Results on the developmental toxicology of lapachol are controversial. Almeida et al. (1999), observed that female rats treated with $100 \mathrm{mg}$ of lapachol/kg body weight from $1^{\text {st }}$ to the $5^{\text {th }}$ post insemination day (PID) had $100 \%$ resorption rate in rats killed at $21^{\text {st }}$ pregnancy day, but other observations with the administration of $100 \mathrm{mg}$ of lapachol $/ \mathrm{kg}$ body weight from PID-3 to PID-5 did not show alteration in the implantation index and did not increase the number of resorptions in rats (Almeida et al., 1999). In order to understand the effect of lapachol on the early development of the rat embryo, in the present study rats were treated during the first seven days of pregnancy and the embryo development was investigated.

\section{MATERIALS AND METHODS}

\section{Plant material}

Lapachol, obtained from Tabebuia ochracea was purchased from PVP Pharmaceutic Laboratory (Piauí state, Brazil) with $63 \%$ purity, and then processed by the Quality Control Lab. from Faculdade de Farmácia e Bioquímica, Universidade Federal de Juiz de Fora (UFJF), where $98 \%$ purity was obtained.

\footnotetext{
Animals

Three-month-old female Wistar rats, weighing $175 \pm 10 \mathrm{~g}$, were obtained from the vivarium of the Centro de Biologia da Reprodução (UFJF), where they were born and reared according to previously described procedures (Guerra et al., 2001; Guerra et al., 1999). Females were inseminated by males of proven fertility, and the presence of spermatozoa in the vaginal smear was considered as the first day pos insemination (PID).

\section{Test protocol}

Pregnant rats were treated from the first to the fourth PID and to evaluate the implantation period, from PID-5 to PID-7.

Dose: $100 \mathrm{mg}$ of lapachol/kg of body weight (L100), via oral gavage/once a day. Lapachol was solved in hydroalcoholic solution $(50 \%$ alcohol:50\% water).

Experimental groups: 10 animals per group.

Control -C (1mL of distilled water);
}

Vehicle -V (1mL of hydroalcoholic solution); Lapachol -100 (L-100).

Pregnant rats were weighed on the first day of pregnancy at the beginning and end of the treatment, and on the euthanasia day. During the experiment, mothers were observed in order to indirectly detect clinical manifestations of toxicity such as death, piloerection, slow or fast locomotion in the cage, diarrhea or vaginal bleeding and reduction of food intake. Daily food intake was estimated by weight difference between the pellet chow placed in the morning and what was left the next morning (Khera, 1984, Manson and Kang, 1994).

\section{EXPERIMENT I - Pre-implantation period}

To evaluate the pre-implantation period, in the morning of PID-5, mothers were killed (total exsanguination under anesthesia - death was confirmed by stopped cardiac beat.). Oviducts and uterine cornua were removed. Oviduct was excised and the ovarian and uterine ostia were identified. The later was canulated and washed with saline. The washing was collected into embryonic glass and examined under stereomicroscopy in order to count and to identify the development phase (Forcelledo et al, 1981; Ortiz et al., 1989): twocell, morula, and blastocyst (early - blastocoel partially formed or latter blastocyst - large and defined blastocoel). Each uterine cornua was cut at the tubal end and above the cervix and then was submitted to the same procedure of washing and examination of the flushing.

\section{EXPERIMENT II - Implantation period}

To observe the effect of lapachol during the implantation period, animals were sacrificed on the PID-15 as described above. The reproductive tract was removed. Each ovary was dissected and their gestational corpora lutea were counted (Cummings, 1990). Uterine cornua were longitudinally incised and embryo and placenta were visualized. The implantation sites were numbered from the left to the right ovarian end. The number of resorptions and of live and dead fetuses was counted. The criteria for determination of live, or dead fetuses were the presence, or absence of blood circulation or cardiac beat, observed under stereomicroscopy (Gleich and Frohberg, 1977). Each fetus and placenta was removed and the litter was weighed (KaplanKraicer et al., 1995). The fetuses were examined to observe the face, upper and lower limbs 
development. The percentage of: pre-implantation embryo loss ( $\mathrm{LprE}=$ [number of total corpora lutea - number of embryos/number of total corpora lutea] $\times 100$ ) according to Damasco and Lemônica (1999); implantation (implants = embryo numbers plus resorption numbers) (Ford, 1982), and resorptions (total resorptions/total implants $\times 100$ ) were calculated.

\section{Statistical Analysis}

Statistical analyses were performed using one way analysis of variance test for continuous data, Student ' $t$ ' paired test to compare maternal body weight before and after treatment, Chi square or exact Fisher to analyze the proportions. Test significance: $\alpha=0.05$. The experimental design approved by the local Animal Ethical Committee being (Certificate number 008 2002).

\section{RESULTS}

No signs of toxicity such as piloerection, diarrhea, vaginal bleeding or alteration of locomotion were observed all experimental groups. Mothers' weights from all experimental groups are expressed in Table 1.

Table 1 - Body weight (g) of control, vehicle and lapachol - treated mothers from experiment I or experiment II (pre-implantation and implantation period, respectively).

\begin{tabular}{ccccc}
\multirow{2}{*}{ Experiments } & PID & \multicolumn{3}{c}{ Weight/Group } \\
\cline { 3 - 5 } & 1 & Control $(\mathbf{n = 1 0})$ & Vehicle $(\mathbf{n}=\mathbf{1 0})$ & Lapachol $(\mathbf{n}=\mathbf{1 0})$ \\
\hline \multirow{2}{*}{ Experiment I } & 4 & $165.4 \pm 10.4$ & $168.3 \pm 15.3$ & $156.8 \pm 15.5$ \\
& 5 & $171.6 \pm 12.4$ & $165.1 \pm 18.7$ & $155.6 \pm 14.7$ \\
& 1 & $175.1 \pm 11.8$ & $164.4 \pm 18.2$ & $157.8 \pm 15.8$ \\
\hline \multirow{2}{*}{ Experiment II } & 5 & $186.0 \pm 11.2$ & $162.7 \pm 12.5$ & $166.7 \pm 10.4$ \\
& 7 & $186.7 \pm 10.1$ & $172.8 \pm 13.5$ & $178.5 \pm 12.1$ \\
& 15 & $213.5 \pm 11.6$ & $201.2 \pm 18.7$ & $171.1 \pm 13.2$ \\
\end{tabular}

PID $=$ Post insemination days. Results are expressed in mean \pm standard deviation, $\mathrm{n}=10$.

There was no loss of weight during the experiment period. Food intake was similar in all experimental groups, except in the lapachol-treated animals, which had reduced food intake during the treatment but recovered on the day after treatment (results not shown). No embryos were collected in the uterine tube flushings.

Table 2 - Experiment I. Total embryos collected, total blastocyst stage, total latter blastocyst, \% of blastocyst to total embryos and \% of latter to total blastocysts in rats from experiment I.

\begin{tabular}{lccc}
\multicolumn{1}{c}{ Observations } & Control & Vehicle & Lapachol \\
\hline Mean embryos/mother & $10.2 \pm 1(10)$ & $9.1 \pm 1(10)$ & $10.4 \pm 1(10)$ \\
Total lives embryos & 102 & 91 & 104 \\
Total corpora lutea & 109 & 100 & 112 \\
Pre-implantation embryo loss $(\%)$ & $6.4(7 / 109)$ & $9.0(9 / 100)$ & $7.1(8 / 112)$ \\
Total blastocyst & 92 & 87 & 87 \\
Latter blastocyst & 85 & 81 & 73 \\
$\%$ blastocyst* & 90.2 & 95.6 & 83.6 \\
$\%$ latter blastocyst** & 92.3 & 93 & 83.9 \\
\hline
\end{tabular}

* (Total blastocysts / total embryos) X 100. ** (Total latter blastocysts / total blastocysts) X 100.

There was no significant difference among the proportion of blastocysts, or the proportion of latter blastocysts among the groups ( $>0.05)$. No alteration of external morphology of the fetuses was observed. The data on reproductive performance in control, vehicle and treated rats are expressed in the table 3 . 
Table 3 - Experiment II. Mean and standard deviations of reproductive performance data of control, vehicle and lapachol-treated rats during the implantation period.

\begin{tabular}{lccc}
\hline Groups & Control $(\mathbf{n}=\mathbf{1 0})$ & Vehicle $(\mathbf{n}=\mathbf{1 0})$ & Lapachol $(\mathbf{n}=\mathbf{1 0})$ \\
\hline Mean Embryos/Mother* & $11.1 \pm 2(10)$ & $10.9 \pm 2(10)$ & $11.4 \pm 2(10)$ \\
Pre-implantation embryo loss (\%) & $9.7(12 / 123)$ & $6.0(7 / 116)$ & $6.5(8 / 122)$ \\
Implantation (\%) & $89.4(111 / 123)$ & $94.0(109 / 116)$ & $89.2(114 / 122)$ \\
Resorptions (\%) & $4.5(5 / 110)$ & $3.7(4 / 109)$ & $14.9(17 / 114)^{* *}$ \\
Placenta weight (mg)* & $159.7 \pm 3.5(10)$ & $161.2 \pm 3.0(10)$ & $142.2 \pm 6.6(10)^{* *}$ \\
Fetuses weight / litter (mg)* & $167.1 \pm 5.4(10)$ & $175.6 \pm 2.6(10)$ & $149.8 \pm 1.4(10)^{* *}$ \\
\hline
\end{tabular}

* Expressed as mean and standard deviations (number of rats examined).

There was no significant difference among the groups. ${ }^{* *} \mathrm{p}<0.01$ in relation to other groups.

\section{DISCUSSION}

Khera (1985) correlated the low frequency of fetal malformations to the maternal weight reduction and later defined maternal toxicity as transient, or permanent alterations in the maternal physiology with potential to cause adverse effects in the offspring during the embryo-fetal and post-natal development (Khera, 1987). Maternal toxicity can be observed through different approaches such as the clinical observation of body weight loss, locomotor alteration, diarrhea, piloerection, food intake reduction and maternal deaths (Khera, 1984; 1987). In the present work, no clinical signs of maternal toxicity, no loss of body weight and no alteration in food intake were observed, as also was obtained by Guerra et al. (1999, 2001). In a previous work (Carmo, 2004), pregnant rats treated with $100 \mathrm{mg}$ of lapachol $/ \mathrm{kg}$ of body weight showed no significant differences in plasmatic levels of Glutamic Pyruvic Transaminase and urea. Therefore, it can be inferred that lapachol was not toxic to female rats. The female reproductive performance as judged by preimplantation loss (when higher than $10 \%$, could be reproductive failure; Wilson, 1980) and number of corpora lutea seemed to be similar in both experimental groups, hence it was possible to assume that the reproductive performance of both groups were similar.

\section{Experiment I. Pre-implantation}

During the first days (2 - 5) of development, the embryo remained isolated in the oviduct by the occlusion of isthmus-ampular and uterine-tubal junctions. In this region, there were nutrients and specific factors needed for its survival and development until the blastocyst phase, at which time the utero-tubal junction opened for the blastocyst to pass into the uterine cornua (Moore and Croxatto, 1988; Croxatto et al., 1991). Direct or indirect effects of xenobiotics must cause alterations in the pre-implantation embryo development. With the direct effects, the conceptus is affected and in the indirect one, the oviduct transport can be modified, the synchrony of uterus-embryo is lost and blastocyst implantation is inhibited (Roblero et al., 1987).

It could be assumed that no asynchrony of uterusembryo was observed since the embryos obtained on the fifth day, mostly at the blastocyst stage, were obtained from the uterine cornua and no embryos were observed from the oviduct flushings. The proportion of pre-implantation embryonic loss correlated the number of corpora lutea and the number of embryos (Damasco and Lemônica, 1999). The difference between corpora lutea and total embryo collected represents the number of pre-implantation loss. As no difference was observed among the groups, it seemed reasonable to say that lapachol did not cause the death of embryos.

The blastocyst phase is the end point of the preimplantation embryonic development. The mean number of blastocysts and this proportion in relation to the total pre-implantation embryos were similar in all experimental groups hence, it was assumed that lapachol does not interfere with the factors needed for the embryo growth, or with the evolution of its development. Such data were corroborated with the demonstration that the number of expanded blastocysts was similar in all experimental groups. These observations seemed to suggest that lapachol was not toxic to the preimplantation phase of embryo development. Almeida et al. (1988) treated rats from the $1^{\text {st }}$ to the $5^{\text {th }}$ pregnancy day and reported $100 \%$ of resorptions when animals were killed on day 21 of pregnancy. The present work did not show morphological alterations, or reduced number of 
embryos collected, neither a change of the proportion of blastocysts when animals were treated during the first four days of pregnancy (pre-implantation period) with same dose used by the former authors. Meanwhile, a normal morphological appearance was not sufficient to guarantee a healthy embryo and could be compatible with chromosomal alterations that resulted in the death of the embryo after implantation. Also, as observed by Holemans et al. (2003), alterations in the early embryo might become apparent only in adulthood.

\section{Experiment II. Implantation}

The implantation proportion correlates the number of implantation sites and the number of corpora lutea (Kato et al., 1979). As the corpora lutea resulted of ovulatory follicles that probably released an oocyte, it was possible to assume that the implantation index was an indirect way to observe the number of ovulations that resulted in fertilized oocytes and in implanted blastocysts. As no significant difference was observed among the experimental groups, it seemed reasonable to say that lapachol did not alter the process of blastocyst implantation.

After implantation, the embryo was followed by fetal development, or death. The death of an embryo after implantation is observed as a resorption - which is characterized as 'in situ' lyses of embryos or fetuses (Kalter, 1980). The resorptions proportion correlates the number of resorptions and the total number of implants - as higher the proportion, as greater the number of dead embryos. There was a significantly higher proportion of resorptions in lapachol treated mothers, hence it was possible to assume that lapachol was toxic to the embryos, causing its death after implantation. This toxic effect was confirmed by the lower body weight of fetuses and placentae in lapachol treated mothers. Normal fetal and organs growth and development were determined by a complex interplay between genetic, immunological, endocrinological, nutritional, vascular and environmental influences. A disturbance in one of these factors would disrupt normal growth and development (Chahoud et al., 1999).

It is known that when a toxic agent causes death, or fetal growth delay without causing malformations, it can be related to the fact that it interferes with vital processes such as glycolysis, mitochondria function or membrane integrity
(Manson and Wise, 1991). Lapachol is an antiproliferative agent (Santana et al., 1968; Muller et al., 1999; Dinnen and Ebisuzaki, 1997). The mechanism of its antimitotic effect is due to mitochondrial oxidation and phosphorylation inhibition (Santana et al., 1968), antagonism of K vitamin reactions (Dinnen and Ebisuzaki, 1997), or generation of reactive oxygen species (Muller et al., 1999). During early organogenesis, the embryo is in a state of relative hypoxia, with predominance of anaerobic glycolysis (Brison and Leese, 1994; Shepard et al., 2000) and mitochondria present lamellated cristae, indicating its maturity by the limb bud stage (Shepard et al., 2000). Such data leads to doubts regarding the toxic effects related to alterations in mitochondrial function and glycolysis. According to Holemans et al. (2003) and Ergaz et al. (2005) the fetuses body weight reduction could be related with nutrition, maternal metabolism and placental vascularization alterations. Maternal clinical observations (body weight, food and water intake, piloerection, diarrhea and others), as well as plasmatic levels of glutamic pyruvic transaminase as previously demonstrated (Carmo, 2004) were similar between lapachol treated and control rats, which suggested that there were no alterations in maternal nutrition and metabolism.

Vascular placental pathology is a significant contributor for reduced growth in the intrauterine life (Ergaz et al., 2005). Placentae from lapachol treated animals were significantly smaller than those from control and vehicle groups, suggesting some alterations in these organs but as an histopathological analysis was not performed, it was impossible to elucidate the cause of this weight reduction.

In conclusion, in the present experimental design, lapachol administration $(100 \mathrm{mg} / \mathrm{kg}$ body weight) seemed not to cause toxic effects to pregnant rats. The number and the morphology of embryos, during oviduct development (pre-implantation period), did not seem to be affected by this drug, but during the implantation period, lapachol was toxic causing the death of embryos and intrauterine growth retardation.

\section{ACKNOWLEDGMENTS}

This research was partly supported by CAPES, CNPq and WHO. Special thanks go to Mr. Paulo Sérgio do Carmo for technical assistance, to Dr 
Amaury Teixeira Leite Andrade and Luciana Valente Borges for reviewing the English version of this manuscript.

\section{RESUMO}

O Lapachol é uma naftoquinona, extraída de plantas do gênero Tabebuia (família Bignoneaceae), que apresenta múltiplas atividades terapêuticas. Estudos prévios sobre o efeito do lapachol no início do desenvolvimento embrionário de ratas são controversos. No presente trabalho ratas Wistar prenhes foram tratadas com lapachol do $1^{\underline{0}}$ ao $4^{0}$ dias pós-inseminação (período de pré-implantação) e do $5^{0}$ ao $7^{0}$ dias (período de implantação do blastocisto). As mães foram sacrificadas no $5^{0}$ o e no $15^{0}$ dia pós-inseminação. Contaram-se corpos lúteos, embriões em fase de pré-implantação, blastocistos, fetos vivos e mortos e reabsorções.Fetos e placentas foram pesados. Não ocorreram indícios de toxicidade materna.O número e a morfologia dos embriões durante o desenvolvimento tubário não foi afetado pela droga, mas durante o período de implantação o lapachol foi tóxico, causando morte de embriões e retardo de crescimento intra-uterino.

\section{REFERENCES}

Almeida, E. R. (1990), Antiinflammatory action of lapachol. J. Ethnopharmacol., 29, 239-241.

Almeida, M. E.; Brandão, M. A.; Guerra, M. O. and Peters, V. M. (1999), Avaliação Preliminar do Efeito interceptivo do Lapachol em ratas Wistar. Bol. Cent. Biol. Reprod., UFJF, 18, 37-48.

Almeida, E. R. et al. (1988), The action of 2-hydroxy 3- (3-methyl -2-butenyl) -1,4-naphtoquinone (lapachol) in pregnant rats. Revista Portuguesa de Farmácia, 38, 21-23.

Andrade-Neto, V. F.; Goulart, M. O. F.; Silva Filho, J. F.; Silva, M. J.; Pinto, M. C. F. R.; Pinto, A. V.; Zalis, M. G.; Carvalho, L. H. and Krettli, A. U. (2004), Antimalarial activity of phenazines from lapachol, lapachone and its derivatives against Plasmodium falciparum in vitro and Plasmodium berghei in vivo. Bioorg. Med. Chem. Lett., 14, 1145-1149.

Austin, F. G. (1974), Schistosoma mansoni chemoprophylaxis with dietary lapachol. Am. J. Trop. Med. Hyg., 23, 412-419.

Balassiano, I. T.; Paulo, S. H.; Silva, N. H.; Cabral, M. C. and Carvalho, M. G. C. (2005), Demonstration of the lapachol as a potential drug for reducing cancer metastasis. Oncol. Rep., 13, 329-333.
Binutu, O. A.; Adesogan, K. E. and Okogun, J. L. (1996), Antibacterial and antifungal compounds of Kigelia pinnata. Planta Med., 62, 352-353.

Brison, D. R. and Leese, H. J. (1994), Blastocoel cavity formation by preimplantation rat embryos in the presence of cyanide and other inhibitors of oxidative phosphorylation. J. Reprod. Fertil., 101, 305-309.

Carmo, J. C. (2004), Morfogênese embrionária em ratos (Rattus Norvegicus Berkenhout, 1769) após introdução de lapachol no matroambiente. MSc dissertation, Universidade Federal de Juiz de Fora, Juiz de Fora, Brazil.

Carvalho, L. H.; Rocha, E. M. M.; Raslan, D. S.; Oliveira, A. B. and Krettli, A. U. (1998), In vitro activity of natural and synthetic naphthoquinones against erythrocytic stages of Plasmodium falciparum. Braz. J. Med. Biol. Res., 21, 485-487.

Chahoud, I.; Ligensa, A.; Dietzel, L. et al. (1999), Correlation between maternal toxicity and embryo/fetal effects. Reprod.Toxicol., 13, 375-381.

Chiari, E.; Oliveira, A. B.; Raslan, D. S. et al. (1991), Screening in vitro of natural products against blood forms of Trypanosoma cruzi. Trans. R. Soc. Trop. Med. Hyg., 85, 372-374.

Croxatto, H. B.; Ortiz, M. E.; Forcelledo, M. L.; Fuentealba, B.; Noé, G. et al. (1991), Hormonal control of ovum transport through the rat oviduct. Arch. Biol. Med. Grap., 24, 403-410.

Cummings, A. M. (1990), Toxicological mechanisms of implantation failure. Fundamental and Applied Toxicology, 15, 571-579.

Damasco, D. C. and Lemônica, I. P. (1999), Effect of Rosemary (Rosemarinus officinalis L.) extract in pregnant rats within preimplantation period. Rev. Bras. Toxicol., 12, 47-54.

Dinnen, R. D. and Ebisuzaki, K. (1997), The search for novel anticancer agents: a differentiation-based assay and analysis of a folklore product. Anticancer Res., 17, 1027-1033.

Duarte, D. S.; Dolabela, M. F.; Salas, C. E. et al. (2000), Chemical characterization and biological activity of Masfadyena ungüis-cati (Bignoneaceae). $J$. Pharm. Pharmacol., 52, 347-352.

Ergaz, Z.; Avgil M. and Ornoy A. (2005), Intrauterine growth restriction - etiology and consequences: What do we know about the human situation and experimental animal models? Reprod. Toxicol., 20, 301-322.

Felício, A. C.; Chang, C. V.; Brandão, M. A.; Peters, V. M. and Guerra, M. O. (2002), Fetal growth in rats treated with lapachol. Contraception, 66, 289-293.

Forcelledo, M. L.; Vera, R. and Croxatto, H. B. (1981), Ovum transport in pregnant, pseudopregnant, and cyclic rats and its relationship to estradiol and progesterone blood levels. Biol. Reprod., 24, 760-765.

Ford, W. C. L. (1982), The effect of 6-deoxy-6 fluoroglucose on the fertility of male rats and mice. Contraception, 25, 534-545. 
Gentry, A. H. (1992), Flora Neotropica: Bignoneaceae: Part. II (Tubeteromeae). New York: The New York Botanical Garden. pp. 226-230.

Gleich, J. and Frohberg, H. (1977), General teratological techniques. In.: Neubert, D. et al. (Eds.). Methods in prenatal toxicology. Evaluation embryotoxic effects in experimental animal. Massachusetts, PSG Publishing Co. pp. 94-102.

Grazziotin, J. D.; Schapoval, E. E. S. and Chaves, C. G. (1992), Phytochemical and analgesic investigation of Tabebuia chrysotricha. J. Ethnopharmacol., 36, 249-251.

Guerra, M. O.; Manzoni, A. S.; Brandão, M. A. and Peters, V. M. (1999), Interceptive effects of lapachol in rats. Contraception, 60, 305-307.

Guerra, M. O.; Manzoni, A. S.; Brandão, M. A. and Peters, V. M. (2001), Toxicology of lapachol in rats: embryolethality. Rev. Bras. Biol., 61, 171-174.

Guiraud, P.; Steiman, R.; Campos-Takaki, G. M.; Seigle-Murandi, F.; and Simeon de Buochberg, M. (1994), Comparison of antibacterial and antifungal activities of lapachol and beta-lapachone. Planta Med., 60, 373-374.

Hodnett, E. M.; Wongwiechintana, C.; Duan III, W. J. and Mars, P. (1983), Substituted 1,4-naphthoquinones vs. the ascitic sarcoma 180 of mice. J. Med. Chem., 26, 570-574.

Holemans, K.; Aerts, L. and Van Assche F. A. (2003), Fetal growth restriction and consequences for the offspring in animal models. J. Soc. Gynecol. Investig., 10, 392-399.

Houghton, P. J.; Photiou, A.; Uddin, S. et al. (1994), Activity of extracts of Kigelia pinnata against melanoma and renal carcinoma cell. Planta Med., 60, 430-433.

Kalter, H. (1980), The relationship between congenital malformations and prenatal mortality in experimental animals. In: Potter, I. and Hook, E. B. (Eds.). Human Embryonic and Fetal Death. New York: Academic Press. pp. 29-44.

Kaplan-Kraicer, R.; Bardin, C. W. and Shalgi, R. (1995), Anordil and RV 486 synergize to produce preimplantation pregnancy loss by increasing embryo transport (rat). Contraception, 51, 141-146.

Kato, H.; Morishige, W. K. and Rotchild, I. (1979), A quantitative relationship between the experimentally determined number of conceptuses and corpus luteum activity in pregnant rat. Endocrinology; 105, 846-850.

Khera, K. S. (1987), Maternal toxicity of drugs and metabolic disorders - a possible etiologic factor in the intrauterine death and congenital malformation: a critique on human data. Crit. Rev. Toxicol., 17, 345-375.

Khera, K. S. (1985), Maternal toxicity- a possible etiological factor in embryo-fetal deaths and fetal malformations of rodent-rabbit species. Teratology, 31, 129-153.
Khera, K. S. (1984), Maternal toxicity: a possible factor in fetal malformations in mice. Teratology, 29, 411-416.

Knecht, W.; Henseling, J. and Loffler, M. (2000), Kinetics of inhibition of human and rat dihydroorotate dehydrogenase by atovaquone, lawsone derivatives, brequinar sodium and polyporic acid. Chem. Biol. Interact., 124, 61-67.

Kumagai, Y.; Nakajima, H.; Midotikawa, K. et al. (1998), Inhibition of nitric oxide formation by neuronal nitric oxide synthase as a quinone reductase. Chem. Res. Toxicol.,11, 608-613.

Lagrota, M. H. C.; Wigg, M. D.; Aguiar, A. N. S.; Pinto, A. V. and Pinto, M. C. R. (1987), Antiviral activity of naphthoquinones. I. Lapachol derivatives against enteroviruses. Rev. Lat-Amer. Microbiol., 29,15-20.

Lima, N. M. F.; Santos, A. F.; Porfírio, Z.; Goulart, M. O. F. and Sant'Ana, A. E. G. (2002), Toxicity of lapachol and isolapachol and their potassium salts against Biomphalaria glabrata, Schistosoma mansoni cercariae, Artemia salina and Tilapia nilotica. Acta Trop., 82, 43-47.

Linardi, M. C. F.; Oliveira, M. M. and Sampaio, M. R. P. (1975), A lapachol derivative active against mouse lymphocytic leukemia P-388. J. Med. Chem., 18, 1159-1161.

Lopes, J. N.; Cruz, F. S.; Docampo, R. et al. (1978), In vitro and in vivo evaluation of the toxicity of 1,4naphthoquinone and 1,2-naphthoquinone derivatives against Trypanosoma cruzi. Ann. Trop. Med. Parasitol., 72, 523-531.

Manson, J. M. and Kang, Y. J. (1994), Test methods for assessing female reproductive and developmental toxicology. In: Hayes, A. W. (Ed.). Principles and Methods of Toxicology, New York: Raven Press. pp. 989-1034.

Manson, J. M. and Wise, L. D. (1991), Teratogens. In: Casarett; Doull's. Toxicology. $4^{\text {th }}$ ed. New York: Pergammon Press. pp. 226-254.

Moore, G. D. and Croxatto, H. B. (1988), Effects of delayed treatment with estrogen on the transport of microspheres by the rat oviduct. J. Reprod. Fertil., 83, 795-802.

Morrison, R. K.; Brown, D. E.; Oleson, J. J. et al. (1970), Oral toxicology studies with lapachol. Toxicol. Appl. Pharmacol., 17, 1-11.

Muller, K.; Sellmer, A. and Wiegrebe, W. (1999), Potential antipsoriatic agents: lapachol compounds as potent inhibitors of HaCaT cell growth. J. Nat. Prod., 62, 1134-1136.

Ortiz, M. E.; Llados, C. and Croxatto, H. B. (1989), Embryos of different ages transferred to the rat oviduct enter the uterus at different times. Biol. Reprod., 41, 381-384. 
Pinto, A. V.; Pinto, M. C. R. and Gilbert, B. (1987), Activity of some naphtoquinones on blood stream forms of Trypanossoma cruzi. Trans. R. Soc. Trop. Med. Hyg., 81, 60-70.

Pinto, A. V.; Pinto, M. C. R. and Gilbert, B. (1977), Schistosoma mansoni: blockage of cercarial skin penetration by chemical agents: I. Naphthoquinones and derivatives. Trans. R. Soc. Trop. Med. Hyg., 71, 133-135.

Rao, K. V. (1974), Quinone natural products: Streptonigrin (NSC-45383) and lapachol (NSC11905) structure-activity relationships. Cancer Chemo. Rep., 4, 11-17.

Roblero, L. S.; Fernandez, O. and Croxatto, H. B. (1987), The effect of RV 486 on transport, development and implantation of mouse embryos. Contraception, 36, 549-555.

Rothery, R. A.; Chatterjee, I.; Kiema, G.; McDermott, M. T. and Weiner, J. H. (1998), Hydroxylated naphthoquinones as substrates for Escherichia coli anaerobic reductases. Biochem. J., 332, 35-41.

Sacau, E. P.; Estévez-Braun, A.; Ravelo, A. G.; Ferro, E. A.; Tokuda, H.; Mukainaka, T.; Nishino, H. (2003), Inhibitory E.ects of Lapachol Derivatives on Epstein-Barr Virus Activation. Bioorg. Med. Chem., 11, 483-488.

Saizarbitoria, C. T.; Anderson, J. E.; Alfonso, D. and McLaughlin, J. L. (1997), Bioactive furonaphthoquinones from Tabebuia barbata (Bignoneaceae). Acta Cient. Venez., 48, 42-46.

Santana, C. F.; Lima, O. G.; D'albuquerque, I. L.; Lacerda, A. L. and Martins, D. G. (1968), Observações sobre as propriedades antitumorais e toxicológicas do extrato do líber e de alguns componentes do cerne do pau d'arco (Tabebuia avellanedae). Rev. Inst. Antibiot., 8, 89-94.
Santos, A. F.; Ferraz, A. P. L.; Pinto, A. V. et al. (2000), Molluscicidal activity of 2-hydroxy-3-alkyl1,4 naphthoquinones and derivates. Int. J. Parasitol., 30, 1199-1202.

Shepard, T. H.; Muffley, L. A. and Smith, L. T. (2000), Mitochondrial ultrastructure in embryos after implantation. Hum. Reprod., 15, 218-228.

Sieber, S. M.; Mead, J. A. R. and Adamson, R. H. (1976), Pharmacology of antitumor agents from higher plants. Cancer Treat. Rep., 60, 1127-1139.

Silva, T. M. S.; Camara, C. A.; Barbosa, T. P.; Soares, A. T.; Cunha, L. C.; Pinto, A. C.; Vargas, M. D. (2005), Molluscicidal activity of synthetic lapachol amino and hydrogenated derivatives. Bioorg. Med. Chem., 13, 193-196.

Wilson, J. G. (1980), Environmental effects on intrauterine death in animals. In: Potter, I. and Hook, E. B. (Eds.). Human Embryonic and Fetal Death. New York: Academic Press. pp. 12-24.

Received: January 11, 2005; Revised: September 02, 2005; Accepted: August 30, 2006. 